\title{
DERROTAS ELEITORAIS E CARREIRAS POLÍTICAS: OCASO DO PT NO RIO GRANDE DO SUL
}

\author{
Frédéric Louault
}

\begin{abstract}
RESUMO
O objetivo do artigo é mostrar a importância das derrotas na competição eleitoral, revertendo assim o enfoque clássico da análise eleitoral. Muitas vezes esquecido (ou deixado de lado) nos trabalhos de Ciencia Politica, o tema da derrota eleitoral levanta problemáticas cruciais para compreender o jogo politico democrático. Estudando as experiências eleitorais do Partido dos Trabalhadores (PT) no Rio Grande do Sul entre 1982 e 2008, apresentamos alguns desafios das derrotas eleitorais no que diz respeito a construção das carreiras de candidatos e colaboradores: reações às derrotas e aceitação das regras do jogo; mobilização de recursos e mobilidades no campo político; rupturas políticas e saídas do espaço político profissional. Na primeira parte desse trabalho, propomos o modelo sociológico da caminhada (e mais precisamente o "submodelo bifurcativo") como quadro de análise que permite renovar a análise clássica das relações entre derrotas eleitorais e carreiras políticas. Sobre essa base, mostramos que algumas derrotas podem constituir elementos de perturbação e influenciar o percurso do pessoal político. Seguidamente, concluímos o trabalho apresentando algumas formas concretas de bifurcações direta ou indiretamente geradas por derrotas eleitorais: as bifurcações menores e as bifurcações radicais.
\end{abstract}

PALAVRAS-CHAVE: competição eleitoral; análise eleitoral; derrota; Partido dos Trabalhadores; Rio Grande do Sul.

\section{INTRODUÇÃO ${ }^{1}$}

Apesar de cada pleito eleitoral fazer muito mais perdedores do que eleitos, poucos trabalhos de Ciências Sociais fizeram da derrota e do fracasso na política uma variável central de estudo (BON \& BURNIER, 1985; MILLOUD, 2000; ABELES, 2005). A história eleitoral é escrita pelos vencedores. Muitas vezes esquecido (ou voluntariamente deixado de lado) nos trabalhos de Ciência Política, o tema da derrota eleitoral levanta problemáticas cruciais para compreender o jogo politico democrático. O tratamento mais sério desse tema encontra-se na Ciência Política norte-americana, na qual vários aspectos políticos e sociológicos da derrota eleitoral foram abordados desde a década de 1970, dando lugar a intensos intercâmbios científicos. Apesar de nenhum desses trabalhos ter apresentado uma reflexão conceitual sobre o fracasso e a derrota, os diferentes autores que têm trabalhado essa temática mostraram que uma análise das derrotas

\footnotetext{
1 O autor agradece a Ernesto Seidl pelos comentários que fez a uma versão anterior do presente artigo.
}

eleitorais pode oferecer importantes chaves de compreensão do jogo político. Alguns autores procuraram compreender as causas da derrota; prever as derrotas para melhor evitá-las (ZULLOW \& SELIGMAN, 1990; SCHEIER \& CARVER, 1990; GILMOUR \& ROTHSTEIN, 1996). Outros insistiram nas conseqüências do malogro político sobre a aceitação das regras do jogo democrático (KIM, 1970; KIM \& RACHETER, 1973), ou interessaram-se pela derrota eleitoral como fator de saída da vida política (RAY, 1976; HIBBING, 1982; HERRICK \& NIXON, 1996; MONCRIEF, 1998).

O presente artigo inscreve-se na continuidade dessa última abordagem. Invertendo o enfoque clássico da análise eleitoral, o objetivo é mostrar a importância das derrotas para a competição eleitoral e apresentar alguns desafios levantados pelas derrotas eleitorais no que diz respeito às carreiras políticas. Será que as derrotas eleitorais têm uma influência sobre as trajetórias do pessoal político profissional? Nesse caso, como essa influência carateriza-se? Por meio de um estudo do pessoal político do Partido dos Trabalhadores (PT) no estado do Rio Grande do Sul entre 1982 
e 2008, procuramos saber se certos tipos de derrotas eleitorais podem provocar bifurcações e gerar redefinições - ou até rupturas - nos percursos do pessoal político. Esse estudo apóiase em um trabalho de campo efetuado em dois tempos entre 2005 e 2008 (um mês em 2005, seguido de oito meses em 2007 e 2008) no âmbito de uma tese de doutorado em Ciência Política cuja base metodológica é a grounded theory (teoria enraizada), como desenvolvida por Barney Glaser e Anselm Strauss, da Escola de Chicago (GLASER \& STRAUSS, 1967; GLASER, 1998). As hipóteses, a conceitualização e a teorização decorrem dos dados recolhidos durante o trabalho empírico.

Para nosso estudo, entrevistas semidiretivas foram realizadas a partir de uma amostra teórica de 45 pessoas que fazem ou fizeram parte de PT do Rio Grande do Sul, e que sofreram experiências de derrotas eleitorais ${ }^{2}$. Entre essas, vinte e quatro tiveram pelo menos uma experiência direta de derrota como candidatos entre 1982 e 2008 . Vinte e sete tiveram pelo menos uma experiência indireta de derrota como ocupantes de cargos de confiança. Seis tiveram ao mesmo tempo experiências como candidatos e como colaboradores. No que se refere aos candidatos, a amostra foi preparada de maneira a incluir a maior variedade possível em termos de tipos de derrotas, para cargos de Vereador, Prefeito, Deputado Estadual, Deputado Federal, Governador e Senador. Os 24 candidatos entrevistados totalizaram 70 experiências de derrotas. Cada candidato entrevistado sofreu entre uma e cinco derrotas durante sua carreira política. Essa seleção fez-se entre um número total de 2785 experiências de derrota (cf. Tabela 1).

TABELA 1 - CANDIDATURAS E DERROTAS DO PT-RS, 1982-2008

\begin{tabular}{|c|c|c|c|c|c|c|}
\hline CARGO & ZONA & SISTEMA & $\begin{array}{c}\text { TOTAL } \\
\text { CANDIDATURAS }\end{array}$ & $\begin{array}{c}\text { TOTAL } \\
\text { DERROTAS }\end{array}$ & $\begin{array}{l}\text { TAXA DE } \\
\text { DERROTAS }\end{array}$ & $\begin{array}{c}\text { AMOSTRA } \\
\text { TEÓRICA } \\
\text { DERROTAS }\end{array}$ \\
\hline Vereador & $\begin{array}{c}18 \text { municípios } \\
\text { principais do } \\
\text { RS }^{1}\end{array}$ & $\begin{array}{l}\text { Proporcional } \\
\text { lista aberta }\end{array}$ & 2537 & 2203 & $86,8 \%$ & 25 \\
\hline Prefeito & $\begin{array}{c}18 \text { municípios } \\
\text { principais do } \\
\text { RS }^{1}\end{array}$ & $\begin{array}{l}\text { Majoritário } \\
\text { uninominal }\end{array}$ & 117 & 87 & $74,4 \%$ & 14 \\
\hline $\begin{array}{l}\text { Deputado } \\
\text { Estadual }\end{array}$ & Estado RS & $\begin{array}{l}\text { Proporcional } \\
\text { lista aberta }\end{array}$ & 342 & 293 & $85,7 \%$ & 14 \\
\hline Governador & Estado RS & $\begin{array}{l}\text { Majoritário } \\
\text { uninominal }\end{array}$ & 7 & 6 & $85,7 \%$ & 4 \\
\hline $\begin{array}{l}\text { Deputado } \\
\text { Federal }\end{array}$ & Estado RS & $\begin{array}{l}\text { Proporcional } \\
\text { lista aberta }\end{array}$ & 194 & 159 & $82 \%$ & 9 \\
\hline Senador & Estado RS & $\begin{array}{l}\text { Majoritário } \\
\text { uninominal }\end{array}$ & 8 & 7 & $87,5 \%$ & 3 \\
\hline $\begin{array}{l}\text { Presidente } \\
\text { República }\end{array}$ & Estado RS & $\begin{array}{l}\text { Majoritário } \\
\text { uninominal }\end{array}$ & 0 & 0 & - & 0 \\
\hline TOTAL & & & 3175 & 2785 & $87,7 \%$ & 69 \\
\hline
\end{tabular}

FONTE: o autor.

NOTA : 1. Alvorada, Bagé, Bento Gonçalves, Cachoeirinha, Canoas, Caxias do Sul, Gravataí, Novo Hamburgo, Passo Fundo, Pelotas, Porto Alegre, Rio Grande, Santa Cruz do Sul, Santa Maria, São Leopoldo, Sapucaia do Sul, Uruguaiana e Viamão.

No que diz respeito aos colaboradores, restringimos a amostragem a uma população que ocupou cargos de confiança no poder Executivo do estado do Rio Grande do Sul (perdido pelo PT
2 A expressão "sofrer uma derrota" já nos informa sobre o preconceito negativo que acompanha a categoria ordinária (ou natural) de derrota. 
em 2002) e do município de Porto Alegre (perdido pelo PT em 2004), que foram despojados por razões políticas depois dessas derrotas (spoil system). Escolhemos esses dois casos porque os consideramos exemplares em termos de efeitos colaterais (indiretos) decorrendo das derrotas. Entre os cargos de confiança da administração municipal e da administração estadual, resolvemos constituir uma amostra discriminante, focalizando ex-membros de duas secretarias: as secretarias da Cultura e da Comunicação Social. Em cada um desses orgãos, entrevistamos ocupantes de cargos de confiança de vários níveis (secretários, assessores etc.).

Essa dupla amostra deve permitir-nos analisar a derrota e suas diferentes implicações desde uma perspetiva ampla. O processamento dos dados qualitativos fez-se por meio de um conjunto de instrumentos de codificação e interpretação (codificação aberta, codificação axial e matriz condicional-conseqüencial) propostos pelos autores da grounded theory (STRAUSS \& CORBIN, 2004). Na primeira parte desse trabalho, propomos o modelo sociológico da caminhada (e mais precisamente o "submodelo bifurcativo") como quadro de análise que permite renovar a análise clássica das relações entre derrotas eleitorais e carreiras políticas. Sobre essa base, mostramos que algumas derrotas podem constituir elementos de perturbação susceptíveis de influenciar o percurso do pessoal político. Em seguida, concluímos o trabalho apresentando algumas formas concretas de bifurcações direta ou indiretamente geradas por derrotas eleitorais, as bifurcações menores e as bifurcações radicais.

\section{ESTUDAR AS RELAÇÕES ENTRE DERROTAS ELEITORAIS E CARREIRAS POLÍTICAS}

II.1. Derrotas eleitorais e carreiras políticas na Ciência Política anglossaxã

"Here's to the losers, bless them all" Franck Sinatra, Here's to the losers, 1963.

A relação entre derrotas eleitorais e carreiras políticas foi bastante estudada pela literatura anglosaxã, principalmente do ponto de vista quantitativo. Na linhagem do primeiro artigo de Chong Lim Kim (1970) sobre as reações políticas dos candidatos derrotados em eleições legislativas, vários autores interessaram-se pelas causas da saída dos políticos. Será que a derrota eleitoral pode ser um fator de saída da vida política? A partir do final dos anos 1980, e com o impulso de David Ray, Stephen Frantzich e John Hibbing, um intenso debate abre-se sobre o caráter voluntário ou sofrido das saídas do poder Legislativo dos Estados Unidos e do Canadá. A derrota eleitoral, que é uma causa entre outras de saída política (a saída voluntária por demissão, a saída voluntária em fim de mandato, a demissão forçada por cassação, a doença e o falecimento), toma assim um lugar importante nos estudos sobre as carreiras legislativas. Em 1976, David Ray publica um estudo quantitativo sobre as Câmaras dos Deputados de oito estados dos Estados Unidos, no período 1897-1967 (RAY, 1976). Ele mostra que cada vez mais Deputados buscam a reeleição, e que cada vez mais desses candidatos (incumbents) são efetivamente reeleitos (diminuição da taxa de evicção e de saída). David Ray conclui que a taxa de reeleição aumenta gradualmente e que os riscos para um Deputado perder uma eleição diminui. Em 1982, observando um forte aumento no número de saídas voluntárias do Congresso dos Estados Unidos, John Hibbing procura saber quem deixa voluntariamente o Congresso, e por que razões (HIBBING, 1982). A partir de diversas variáveis (idade, experiência, partido, região, risco incorrido etc.), ele mostra que o perfil das pessoas que se retiram alterou-se entre os anos 1960 e 1970. Mas trata-se sobretudo de um trabalho de fundo sobre as motivações e as carreiras políticas que repõem em causa a tese segundo a qual a reeleição é o objetivo principal de todo político ${ }^{3}$.

Enquanto que John Hibbing segue os seus trabalhos sobre as carreiras legislativas, alguns autores contribuem nos anos 1990 a esses debates. A tese inicial de David Ray será confirmada por um estudo sobre os Deputados da Assembléia Federal dos Representantes, publicada em 1996 por John B. Gilmour e Paul Rothstein. Esses autores mostram que, no período de 1870 a 1988, as carreiras dos Deputados alongaram-se devido a uma dupla pressão, uma diminuição geral das saídas voluntárias e uma diminuição global da taxa de derrotas eleitorais para os candidatos (GILMOUR \& ROTHSTEIN, 1996). Eles indicam que a taxa de derrota aumen-

\footnotetext{
3 Tese à época defendida por Joseph A. Schlesinger (1966) e Stephen E. Frantzich (1978).
} 
tou globalmente entre 1900 e 1930, período durante o qual a diminuição do turn-over legislativo devia-se sobretudo à baixa das saídas voluntárias. Em contrapartida, a taxa de saídas causadas por derrotas teria diminuído muito nas últimas décadas (o que se explicaria com a evolução dos meios e das formas de fazer campanha). Os autores estabelecem finalmente uma relação de causalidade direta entre derrotas eleitorais e saídas voluntárias (relação, contudo, não verificada qualitativamente). Para eles, os membros do Congresso podem ser incitados a candidatar-se se o risco de que sejam derrotados diminuir e "uma diminuição das derrotas pode gerar uma diminuição das saídas" (idem, p. 64). Outro estudo sobre as causas do turnover legislativo, realizado por Garry F. Moncrief a partir de 103 eleições provinciais canadenses (entre 1960 e 1997), mostra que apenas a metade das saídas deve-se a derrotas eleitorais (MONCRIEF, 1998). Aliás, o turnover legislativo médio seria mais alto no Canadá $(37,1 \%$ sobre esse período) do que nos Estados Unidos ou na Austrália (entre 20 e 30\%). G. Moncrief conclui que os deputados das províncias canadenses são menos interessados em construir uma carreira política que os norte-americanos e australianos. Mas ele não explica as razões dessa diferença, como aliás tentaram fazer Michael K. Moore e John Hibbing em um artigo sobre o desencanto dos congressistas estadunidenses (MOORE \& HIBBING, 1992).

Finalmente, dois artigos tentaram - ainda na metade dos anos 1990 - alargar o quadro desses debates. Rebekah Herrick e David L. Nixon publicam em 1996 o primeiro estudo sério sobre as carreiras pós-parlamentares dos Deputados que escolheram retirar-se do Congresso Federal dos Estados Unidos ou que sofreram uma derrota eleitoral (HERRICK \& NIXON, 1996). A análise deles cobre o período de 1971 a 1992 e procura responder às questões seguintes, há uma vida depois do Congresso? Os antigos congressistas permanecem no espaço político profissional após a experiência legislativa? Segundo as conclusões desse estudo, $40 \%$ dos antigos congressistas (que deixaram o Congresso por uma razão que não seja a morte clínica) encontraram outro cargo no espaço político, $50 \%$ continuaram uma atividade política não profissional, e $10 \%$ pararam toda atividade política (263 dos 392 ex-congressistas responderam ao questionário, ou seja, uma taxa de resposta de 67\%). Detalhando os resultados, os autores mostram que entre os Deputados que deixaram o Congresso por causa de uma derrota eleitoral ou por temor de uma derrota eleitoral, $57 \%$ reencontraram outro emprego político, $37 \%$ continuaram uma atividade política não remunerada e apenas $10 \%$ pararam toda atividade política. Mas o conjunto desses estudos restringe a análise ao pessoal político eleito. Os que tiveram uma atividade política como congressistas eleitos já passaram várias etapas de seleção política e têm boa inserção nas redes políticas, o que facilita sua permanência no espaço político profissional. Além disso, nenhum dos trabalhos procura compreender as implicações reais das derrotas eleitorais para o pessoal político. Quais os efeitos das derrotas no que se refere à motivação política? Por que alguns indivíduos seguem ou abandonam a atividade política após uma derrota? Quais são as condições de uma reclassificação política ou de uma tentativa de reinserção na iniciativa privada? As contribuições da literatura anglo-saxã constituem apenas um modelo de análise entre vários possíveis, mas abordam questões fundamentais e abriram perspectivas de estudo importantes para a Ciência Política internacional que não podem ser desconsideradas. Na Ciência Política brasileira, um bom exemplo de aprofundamento dessa temática é o trabalho de Renata Florentino (2008) sobre os parlamentares que desistem da disputa eleitoral.

Decidimos apresentar nesse artigo apenas a parte qualitativa de nossa pesquisa sobre as derrotas eleitorais do pessoal político do PT no Rio Grande do Sul. Isso favorece o descortinamento de algumas das lógicas mais profundas entre os fatores "derrota" e "carreira" e também a conceitualização da derrota. Mas tal escolha não deve ser interpretada como uma desconsideração do tratamento quantitativo. A análise quantitativa também é importante na medida em que permite jogar luz sobre algumas tendências gerais na relação entre carreiras políticas e derrotas eleitorais. Como Anselm Strauss, consideramos que ambos métodos são complementares, nenhum dos modos de pesquisa tendo superioridade em termos de potencial científico e legitimidade acadêmica. Acreditamos que as interações e discussões entre os dois constituem o caminho certo para um melhor entendimento da derrota eleitoral e de suas implicações. 
II.2. Ultrapassar as análises clássicas: a abordagem com o modelo sociológico da caminhada

Essa contribuição quer-se menos ambiciosa do que os trabalhos citados acima. Não se trata de prever as derrotas ou antecipar o comportamento dos atores políticos, mas de observar - como fez por exemplo Brigitte Gaiti após a derrota do ex-Presidente francês Valéry Giscard d'Estaing em 1981 (GAÏTI, 1990)4 algumas consequências possíveis das derrotas sobre a evolução dos percursos políticos. Por isso, decidimos não restringir o quadro de análise ao pessoal político eleito. Abordamos os desafios da derrota em uma perspectiva mais ampla que integra os colaboradores e os cargos de confiança. Isso nos permite estudar de maneira mais completa as reações dos "perdedores" do jogo político e as condições da sua reclassificação (ascensão e prêmio pela derrota ou recessão na escala dos cargos políticos, abandono de atividade política etc.). De um ponto de vista metodológico, um dos desafios principais de um estudo sobre a derrota em política é "questionar o evento imprevisível [...] [como fizeram alguns historiadores], sem reduzi-lo em última instância a uma mecânica de encadeamentos, sem colocálo em lógicas de sentidos retrospectivamente luminosas, sem perder-se na ilusão das origens, sem o ler como uma espécie de fim, como o resultado de um desastre anunciado" (CABANEL \& LABORIE, 2002, p. 1). Várias perspectivas de estudo oferecem-se aos investigadores que se interessam pela derrota eleitoral. Apresentamos aqui quatro, que nos parecem fundamentais: (i) a derrota como evento (ou não evento). Estudar as (re)construções que os atores elaboram a partir da derrota e que lhe dão sentido. Interrogar-se sobre a elaboração da derrota como evento. Interessar-se no "campo emocional [...] que dirige o evento e o estabelece como fenómeno histórico" (FARGE, 2002, p.7); (ii) a derrota como variável

\footnotetext{
4 Brigitte Gaiiti interessa-se, contudo, com os efeitos da derrota em uma perspectiva mais ampla. Analisa a "personalização" da derrota do candidato, bem como certas consequências individuais e coletivas que decorreram da derrota: período de "negociação generalizada", reorganização do partido Union pour la Démocratie Française (UDF), estratégias individuais e mobilidades políticas, transformação dos discursos etc.
}

dependente. Proceder a uma investigação causal que se destina a explicar a derrota. Privilegiada pela Ciência Política anglo-saxã, essa abordagem quer fazer da derrota um fato previsível. Essa corrente de estudo, que o sociólogo francês (e especialista do estudo das crises políticas) Michel Dobry qualifica de ilusão etiológica, "representa geralmente, no estado atual dos nossos conhecimentos, um obstáculo ainda mais importante do que ele parece precisamente em cima de toda suspeita metodológica" (DOBRY, 1986, p. 50); (iii) a derrota como variável independente. Estudar a derrota como ponto de partida, ou seja, como evento fundador (modelo arqueológico). Estudar os efeitos individuais e colectivos da derrota para compreender os desafios pós-eleitorais, mobilidades políticas, instabilidades e evoluções organizacionais, imputações de responsabilidade, desafios de posicionamento etc, (iv) a derrota como variável intermediária. Trata-se de proceder a uma análise dinâmica da derrota, considerando as porosidades entre o antes da derrota, o momento da derrota e o após da derrota. A derrota faz então parte de um processo político mais largo e estruturando que limita o alcance de sua influência.

Essas quatro abordagens não são exaustivas nem certamente exclusivas. A construção de diligências mistas (que misturam várias abordagens) pode permitir - em certas condições -uma melhor inteligibilidade da derrota eleitoral. Reduzir a investigação a modelos puros abre, ao contrário, o risco de limitar o alcance interpretativo das análises e de favorecer um "logicismo um pouco estéril" (DE CONINCK \& GODARD, 1990, p. 48). No que diz respeito à relação entre derrotas eleitorais e carreiras políticas, situamo-nos principalmente na última perspectiva, tomando emprestado ao mesmo tempo a análise acontecimental da derrota. Colocamo-nos nesse sentido na linhagem do modelo sociológico da caminhada ${ }^{5}$. Nesse modelo, os percursos individuais dividem-se em trechos calmos e em momentos decisivos em que tudo é colocado em jogo, em que os destinos bifurcam-se uns com os outros. Ao contrário do modelo arqueológico, não há uma causa presente que contenha o passado

\footnotetext{
5 Para uma apresentação das diferentes interpretações possíveis da abordagem biográfica em Sociologia, ver Coninck e Godard (1990).
} 
e que determina o futuro, mas eventos cujo sentido evolui ao longo do processo. Inserindo as derrotas eleitorais nos processos propriamente ditos de construção das carreiras políticas, procuramos atualizar as relações entre as conexões causais e temporais.

\section{II.3. Temporalidades da caminhada e submodelo bifurcativo}

O modelo da caminhada divide-se em quatro submodelos. Os dois primeiros (submodelo da duração e submodelo diferencial) consideram o tempo como homogêneo e previsível. Inspiramse na filosofia de Bergson, uma filosofia da ação e da duração que reúne de maneira indissolúvel o passado e o futuro. A nossa análise põe, ao contrário, o tempo como heterogêneo e instável. Inscreve-se na linhagem dos dois outros submodelos (um bifurcativo e outro energético) e deve mais a uma filosofia do ato e do momento como proposta por Roupnel. O pensamento roupneliano apresenta o tempo como uma justaposição de momentos. Para Roupnel, o tempo é essencialmente descontínuo e a história é uma agregação de acidentes ${ }^{6}$. O submodelo bifurcativo consiste em estudar os momentos de ruptura como pontos de discontinuidade nos processos. Mais precisamente, se definimos como bifurcação uma reclassificação ou uma saída do espaço político profissional, trata-se de observar o que provoca essa bifurcação. É o que Coninck e Godard qualificam de "lógica de perturbação", estudar as perturbações geradoras de divergências entre caminhadas individuais (idem, p. 37). Para nosso tema de estudo, os elementos de perturbação considerados são as derrotas eleitorais. O lapso de tempos que se escoa entre o momento da perturbação e o momento da bifurcação (ponto crítico) será qualificado de momento crucial. O estudo das derrotas eleitorais permite testar a hipótese segundo a qual a forma e a intensidade da perturbação têm uma influência sobre o tipo de bifurcação.

\footnotetext{
6 Para uma apresentação detalhada da teoria bergsoniana e da teoria roupneliana do tempo, ver Bachelard (1992). Após ter tentado reconciliar em uma síntese intermédia as duas perspectivas (a duração bergsoniana e o momento roupneliano), Bachelard finalmente se aproximou do pensamento de Roupnel.
}

A noção de bifurcação está próxima da noção de "momento decisivo da existência" (turning point) como definida por Andrew Abbott (2001), ou seja, uma mudança curta e brusca que tem consequências que reorientam um processo. Mas utilizar o termo de bifurcação implica insistir mais no caráter imprevisível das situações. Fala-se de bifurcação para designar "situações nas quais uma sequência de ação parcialmente imprevisível produz efeitos duradouros" (GROSSETTI, 2004, p. 15). No caso das derrotas eleitorais, veremos que os atores encontram-se perante acontecimentos parcialmente imprevisíveis, até mesmo surpreendentes (e isso apesar dos eforços para prever os resultados). A imprevisibilidade desses eventos é, contudo, relativa, os indivíduos não têm um controle real sobre o resultado, mas as formas possíveis de saídas podem ser antecipadas e o momento da eleição é determinado. Os atores podem organizar a imprevisibilidade. Nesse sentido, as bifurcações geradas pelas derrotas eleitorais seguem o modelo do cruzamento (idem, p. 19). A análise pelas bifurcações permite igualmente atualizar as relações entre várias temporalidades, mostrando como eventos que se produzem no curto prazo ou no instante podem ter efeitos sobre processos a médio ou até longo prazo. $\mathrm{O}$ fato de o tempo breve da crise influenciar o tempo longo do percurso biográfico (BIDART, 2006, p. 32) introduz uma relativa irreversibilidade do evento. Para o pessoal político, as eleições constituem momentos que poderão abrir redefinições de caminhadas profissionais e até provocar uma exclusão do jogo político e a morte política dos sujeitos.

No entanto, não nos interessamos unicamente pelos eventos que provocam as bifurcações. Também pretendemos observar o que as bifurcações provocam (ou seja, o que elas abrem). Assim, consideramos as características sociopolíticas dos diferentes indivíduos e observamos como essas características influenciam a gestão dos momentos cruciais. O submodelo energético consiste precisamente em estudar os investimentos e as mobilizações de recursos que permitirão ao indivíduo procurar modelar a forma da sua própria bifurcação. É necessário para isso descobrir as características dos recursos, os ritmos e formas das mobilizações, bem como as localizações dos investimentos. Além disso, devese analisar como os indivíduos conseguem antecipar as perturbações e mobilizar seus 
recursos da maneira mais eficiente. Na parte que segue, mostramos que as derrotas são realmente elementos de perturbação suscetíveis de influenciar (por meio dos efeitos instantâneos) as trajetórias do pessoal político. Em seguida, concluiremos o trabalho apresentando algumas formas concretas de bifurcações direta ou indiretamente geradas por derrotas eleitorais.

\section{AS DERROTAS ELEITORAIS COMO ELEMENTOS DE PERTURBAÇÃO NOS PERCURSOS POLÍTICOS}

"É embaraçoso

Acrescentar-se assim à coorte dos perdedores" Noir Désir, Gagnants/Perdants, 2008

As derrotas eleitorais constituem elementos de perturbação para as carreiras políticas na medida em que geram redistribuições na repartição dos cargos de poder. Mostraremos na parte seguinte quais tipos de consequências essas perturbações podem provocar. Mas os tipos de consequências dependem eles mesmos dos tipos de derrotas que enfrentam os indivíduos. A derrota pode ser definida objetivamente como o reconhecimento oficial por um candidato e seu partido de um resultado matematicamente insuficiente para ser eleito, segundo as regras preestabelecidas para essa eleição. Mas nem todas as derrotas têm as mesmas implicações. Em função da ambição de um candidato, dos seus objetivos, do seu percurso político, do investimento realizado na campanha eleitoral e da conjuntura eleitoral, certas derrotas são mais aceitáveis do que outras. Para compreender a ambigüidade da noção de derrota, a noção mais subjetiva de fracasso eleitoral oferece um complemento de definição importante. Permite dar conta da diversidade das candidaturas em termos de objetivos e de ambições políticas e implica uma diferenciação em termos de aceitabilidade das derrotas. O caráter relativo da noção de derrota foi vislumbrado em vários trabalhos de História Militar(VAÏSSE, 1994; CABANEL \& LABORIE, 2002; LARGEAUD, 2006), de Psicologia (LACROIX, 1968; 1969; LAFORGUE 1993) e de Filosofia (ALAIN, 1985; CIORAN, 1993; AUROUX, 1998). Em Ciência Política, poucos trabalhos explicitam a distinção entre derrotas e fracassos. Os dois termos são geralmente - e erradamente - considerados sinônimos. No melhor dos casos, o fracasso foi apresentado como um acontecimento construído pelos atores a partir dos resultados eleitorais (MILLOUD, 2000).

III.1. O momento pós-eleitoral, confusão e decepção

O fracasso é um revés sentido por alguém que vê seus cálculos frustrados, suas esperanças enganadas. $\mathrm{O}$ fracasso eleitoral pode então ser definido como um resultado eleitoral dificilmente aceitável porque não é suficiente para satisfazer as ambições de um indivíduo. Se os resultados ficam abaixo dos objetivos, a ambição é frustrada, a aceitabilidade do resultado diminui e o nível de malogro aumenta. Sem entrar nos detalhes de um cálculo matemático, cabe apresentar um conjunto de variáveis que permitem objetivar o malogro e apreendê-lo mais do que como uma simples construção social. Se a aceitabilidade do resultado depende da relação entre a ambição e os resultados, quanto maior a diferença entre a ambição e os resultados, maior a frustração e maior o nível de malogro.

\section{QUADRO 1 - DERROTA E FRACASSO. DIFERENCIAL ENTRE AMBIÇÃO E RESULTADO}

Como medir a ambição eleitoral? Não se pode medir em termos de resultados previstos a ambição real de um candidato ou de um partido (não se pode confiar no que o candidato anuncia durante a campanha, nem nas previsões das pesquisas que são enviesadas). Mas pode-se medir a ambição considerando vários fatores : a posição pré-eleitoral do candidato (incumbent, challenger ou outsider); sua experiência eleitoral (número de candidaturas e número de mandatos já exercidos); sua trajetória (ascendente ou descendente); a relação entre o cargo desejado para a eleição e o cargo mais elevado já ocupado; o grau de abertura da competicão eleitoral (ratio candidatos-cargos); e os recursos invertidos na campanha (em \% das despesas totais para essa eleição). Assim, a ambição eleitoral de um candidato ou de um partido é considerada alta se um candidato já ocupava um cargo eletivo (incumbent), quando ele tem experiência política, quando a sua trajetória for ascendente, quando a relação entre o cargo desejado e o cargo ocupado for importante (ambição progressiva, como apresentada por David Samuels (2003)), quanto mais aberta a competicão (muitos cargos e poucos candidatos) e quanto maior a inversão. 
Como medir o resultado eleitoral? No que diz respeito à medida do resultado, não se pode limitar ao resultado bruto, dado que o fracasso é independente da vitória ou da derrota (uma vitória pode vir com um fracasso e uma derrota pode não ser um fracasso). Mas o cálculo do resultado pode fazer-se por meio de uma ponderação entre a evolução do número de votos obtidos entre duas eleições (se o candidato já foi candidato para o mesmo tipo de eleição), o resultado obtido (em \% do total das votações) e a diferença entre o resultado obtido e o resultado do último candidato eleito. Quando menor o Resultado Ponderado (RP), maior a frustração relativa (um baixo RP faz crescer o risco potencial de malogro).

FONTE: o autor.

No caso de um fracasso eleitoral, a aceitação do resultado fica difícil porque o resultado é decepcionante (o candidato ou o partido não previa um resultado ponderado tão baixo). A decepção atinge o pessoal político vítima da derrota como um conjunto, e não simplesmente os candidatos (ainda que para os candidatos um sentimento de responsabilidade e de culpabilidade possa acrescentar-se à decepção). É sobretudo o momento da conscientização quanto ao fracasso que tem um papel de desestabilização e produz a decepção. Esse momento concretiza a "discontinuidade essencial do Tempo" (BACHELARD, 1992, p. 15), atomiza a temporalidade e isola o indivíduo. Para Bachelard, o momento representa antes de tudo a solidão do sujeito. No momento pós-eleitoral, o indivíduo em situação de fracasso encontra-se sozinho, ao mesmo tempo separado dos outros e dele mesmo. Abre-se então um processo de deconstruçãoreconstrução, uma situação de fluidez política (DOBRY, 1986), na qual o indivíduo sente uma sensação dupla e paradoxal de liberdade e confusão.

A derrota do Partido dos Trabalhadores nas eleições municipais de 2004 em Porto Alegre é um protótipo de fracasso eleitoral que quebra a temporalidade política e coloca os indivíduos perante a "intuição do instante" (BACHELARD, 1992). O PT governava a cidade de Porto Alegre há quatro mandatos consecutivos (ou seja, 16 anos). A sua gestão era aprovada pela maioria da população e o número de votos recebidos pelos candidatos do PT aumentava a cada eleição municipal desde 1982 (trajetória ascendente). Ainda que o PT tivesse perdido em 2002 o estado do Rio Grande do Sul, uma derrota em Porto Alegre não era imaginada nem para os dirigentes nem para os militantes. Nesse sentido, a negação por parte dos eleitores de mais um mandato em outubro de 2004 foi uma surpresa. Constituiu um choque para numerosos militantes e membros da administração do PT que pensavam esse partido como "imbatível" e definitivamente implantado em Porto Alegre. Erving Goffman explica que o processo que conduz os atores a crer que não podem perder é precisamente "o que faz cair as suas defesas e as compensações que nos protegem em caso de fracasso" (GOFFMAN, 1989, p. 279). Assim, o momento de tomada de consciência do fracasso foi brutal. Gerou uma confusão tão importante que vários membros da administração municipal entraram em depressão nos dias depois da derrota: "A derrota aqui da prefeitura foi pior do que ter perdido meu pai. Não era por que eu ia ficar sem trabalho. Foi muito mais do que isso. Era um desacompanhamento com a gente e com a cidade ao mesmo tempo. [...] Cara, eu não conseguia falar, eu fui para cama, assim, foi uma coisa horrivel. E já passei por tempinhos na vida, dificuldades sérias, importantes. Mas nada a comparar com isso. Porque era um fechamento total. [...] Nos primeiros 20 dias a gente não conseguia... Fazia reunião de trabalho, e tu chorava a metade da reunião, todo mundo, e daí quando um parava outro começava... Uma coisa horrivel" (EXCARGO DE CONFIANÇA DA SECRETARIA MUNICIPAL DA CULTURA DE PORTO ALEGRE ALEGRE E PROFESSORA EM ESCOLA PÚBLICA, 2005; sem grifos no original).

A ênfase de vários indivíduos nos sentimentos vinculados com a dor (e a comparação com a morte de uma pessoa próxima) traduz uma tentativa de exorcizar um mal-estar e reprimir uma potencial desclassificação social. O fracasso produz uma confusão entre as esferas de vida dos indivíduos, a esfera profissional mistura-se com a esfera privada (familiar) e até com a esfera íntima (psicanalítica). No caso do pessoal político do PT, a confusão ainda era facilitada por uma fluidez quase permanente entre atividade política 
e relações pessoais. Essa confusão tem uma influência importante sobre a interação entre o entrevistado e o pesquisador, esse último assumindo às vezes um papel de Psicólogo. É o mesmo sentimento de abandono e queda - embora expresso com mais reservas - que sentiu um antigo Deputado Federal do PT após sua não reeleição em 2002: "Após a campanha, saiu o resultado, eu me lembro, eu devo ter ficado, assim, uma semana em casa. Fiquei em casa. Dormi muito. Estava obviamente deprimido. Eu sempre, quando eu sinto momentos de depressão, assim, eu curo dormindo" (EX-DEPUTADO FEDERAL DO PT-RS, UM, 2007; sem grifos no original).

\section{III.2. O resultado eleitoral como catalisador de frustrações}

Após o momento de confusão e decepção, o resultado eleitoral também pode desempenhar subsequentemente um papel de catalisador de frustrações para o pessoal político. O nível de frustração dependerá principalmente do grau de inversão e do tempo de implicação no processo político. Em Porto Alegre, a frustração que se seguiu à derrota de 2004 suscitou questionamentos sobre a perenidade das ações desenvolvidas durante os 16 anos de administração municipal do PT. A maior parte das pessoas entrevistadas confessava-se preocupada em ver o trabalho da administração aniquilidado pela causa da entrada em função da equipe do novo Prefeito, José Fogaça: "O PT em Porto Alegre viveu muito em função da institucionalidade, dependendo muito das ações desenvolvidas pelo governo municipal, e jogando todas as nossas energias para que esses projetos dessem certo. [...] Aquele período de outubro a dezembro, após a confirmação da nossa derrota, foi um período bastante difícil. Tinha uns projetos, planos para ofuturo. Durante novembro e dezembro, já tinhamos dado início a projetos importantes, que deixamos assim em andamento. Foi um período de muita frustração" (EXSECRETÁRIO MUNICIPAL DE HABITAÇÃO DE PORTO ALEGRE E FUNCIONÁRIO PÚBLICO, 2005; sem grifos no original).

A repetição das referências aos projetos e ao futuro traduz a dificulade de aceitação da realidade, ultrapassada pelo uso de verbos no passado. A cohabitação entre o passado e o futuro comprova e concretiza essa frustração. Para além dos desafios coletivos da derrota e da perenidade das políticas desenvolvidas, o ser político toma consciência perante a derrota da discontinuidade do tempo político e vê perfilar-se a sua possível morte política. É nesse sentido que o jogo político e o trabalho político suscitam certa angústia (THUILLIER, 1992; ABÉLÈS, 2005). O fracasso tem efeitos sobre as sensibilidades políticas pessoais, sobre a imagem que o ser político constrói deele mesmo e sobre a consideração que ele faz da relação entre passado e futuro. Uma imagem de destruição e inconsistência vem substituir uma imagem lisonjeadora. O indivíduo considera ter contribuído muito em tempo e energia para o bem público; ele não entende essa falta de reconhecimento e a saída imposta pelo jogo. É o que vislumbra esse homem político, vítima de um fracasso eleitoral após ter ocupado cargos eletivos no poder Legislativo durante 18 anos : "No momento, quando saíram os resultados, quando eu vi que eu não fui reeleito, claro que é uma experiência muito ruim. Me impactou muito. Me parecia, e me parece também ainda hoje, qua havia uma injustiça grande. Tinha feito um mandato de Deputado, acho, muito bom, assim, muito estimado, muito valorizado na opinião pública. É muito triste mesmo. Depois de passar 18 anos como Deputado e que tu não é mais, tu te perguntas 'e agora o que que eu sou?' Eu não era nada. Um ex-Deputado" (EXDEPUTADO FEDERAL, DOIS, 2007; sem grifos no original).

$\mathrm{O}$ vocabulário desse ex-Deputado comprova mais uma vez a imensa diferença entre o imaginário pessoal e a realidade. Ele usa nove enfatizações em seis linhas para sublinhar a amplitude da frustração, para concluir com uma negação de sua própria existência física, "eu não era nada". Resulta em uma reflexão introspectiva, uma consideração crítica sobre a condição política e sobre as relações interpessoais, como o exprime esse ocupante de cargo de confiança encontrado cinco meses após a derrota do PT em Porto Alegre em 2004: "O pessoal se dispersou. Todo mundo se dispersou, foi uma luta para procurar o seu espaço, batalhar. Nós estamos em um período de... sofremos com o que aconteceu, sofremos também muito com questões internas, disputas, problemas pessoais na reta final de nosso governo [...]. E assim, nós estamos em uma fase, estamos nos analisando. Quem era amigo realmente, quem não era. (...) Eu, particularmente, me recolhi um pouco, ainda estou em uma fase em que eu preciso cuidar de mim, e de meu trabalho, da minha 
profissão e de meu futuro, das minhas filhas" (EXCARGO DE CONFIANÇA DA SECRETARIA MUNICIPAL DA CULTURA DE PORTO ALEGRE E JORNALISTA FREELANCE, 2005; sem grifos no original).

Essa citação ilustra bem esse processo de gradual fechamento. As considerações vão do geral-coletivo até o particular-íntimo: "todo mundo se dispersou" $\rightarrow$ "sofremos" $\rightarrow$ "problemas pessoais" $\rightarrow$ "estamos nos analisando" $\rightarrow$ "me recolhi" $\rightarrow$ "cuidar de mim" $\rightarrow$ "meu futuro/minhas filhas". Dados quantitativos recolhidos entre 2007 e 2008 com pessoas que sofreram a derrota de 2004 vêm confirmar a difícil aceitação do resultado pelo pessoal político do PT.

Um questionário foi aplicado aos membros do PT que ocupavam em 2007-2008 um cargo de confiança na Câmara Municipal de Porto Alegre e na Assembléia Legislativa do Rio Grande do Sul. À questão "como viveu pessoalmente a derrota de 2004 em Porto Alegre?" as pessoas tinham de dar uma nota para cada sentimento entre zero (se não tivessem sentido) e cinco (se tivessem sentido muito).

TABELA 2 - PERCEPÇÃO DA DERROTA DO PT EM PORTO ALEGRE, 2004

\begin{tabular}{|l|c|c|c|}
\hline $\begin{array}{l}\text { PERCEPÇÃO PESSOAL DADERROTA } \\
\text { (0= NÃO SENTIU, 5 = SENTIU MUITO) }\end{array}$ & $\begin{array}{c}\mathbf{C V} \\
\mathbf{( N = 3 6 )}\end{array}$ & $\begin{array}{c}\mathbf{A L} \\
\mathbf{( N = 3 5 )}\end{array}$ & $\begin{array}{c}\text { TOTAL } \\
\mathbf{( N = \mathbf { ~ }} \mathbf{~ 7 1 )}\end{array}$ \\
\hline Alegria & 1,250 & 0,344 & 0,741 \\
Alívio & 0,292 & 0,344 & 0,321 \\
Frustração/Desilusão & 3,258 & 2,839 & 3,052 \\
Decepção/Tristeza & 4,294 & 3,676 & 3,990 \\
Depressão & 1,966 & 1,788 & 1,872 \\
Aceitação & 1,852 & 2,000 & 1,931 \\
Rejeição & 2,407 & 2,656 & 2,540 \\
Abandono & 1,852 & 2,355 & 2,116 \\
Surpresa & 2,414 & 3,000 & 2,721 \\
Incompreensão & 2,750 & 2,688 & 2,717 \\
Medo do futuro & 2,556 & 1,654 & 2,035 \\
\hline
\end{tabular}

FONTE: o autor.

NOTA: dados extraídos de um questionário aplicado em 2007 e 2008. Setenta e uma pessoas responderam a essa questão (36 da Câmara Municipal e 35 da Assembléia Legislativa). Sessenta e quatro delas tinham participado ativamente (de uma forma ou de outra) na preparação da eleição de 2004 (seja mais de $90 \%$ ) e 35 tinham ocupado um cargo de confiança na administração municipal (seja 49,3\%).

Os sentimentos mais fortemente sentidos pelas pessoas interrogadas são a decepção/tristeza (nota média de 3,99), a frustração/desilusão $(3,05)$, a surpresa $(2,72)$ e a incompreensão $(2,71)$. Em seguida, vem a rejeição, com uma média de 2,54 sobre 5 .

\section{III.3. Da frustração à materialização dos desafios}

Aos efeitos psicológicos da derrota e do malogro vem acrescentar-se uma apreensão muito mais concreta que prolonga a frustração em um temor de médio prazo, a evolução da trajetória profissional e a manutenção das condições materiais de vida. A derrota pode ser sinônimo de perda de recursos simbólicos e materiais para os candidatos (RAGARU, 2004). Mas a maior parte das derrotas também tem efeitos colaterais para o círculo de próximos dos candidatos. São com efeito um conjunto de pessoas que estão envolvidas nas disputas e lutas pelo poder, e para quem a situação profissional depende do veredito das urnas (WEBER, 2004, p. 142). Aos vencedores, a repartição dos cargos (winner takes all), e aos perdedores, a demissão. No poder Legislativo municipal ou estadual, um Deputado do Partido dos Trabalhadores pode empregar legalmente com a verba da Câmara até uns 20 assessores. Essas pessoas correm o risco de perder o emprego se o candidato não for reeleito. No caso dos poderes executivos, o fenômeno de despejo pós-eleitoral torna-se ainda mais importante por causa da prática do spoil system. 
Segundo a lógica do spoil system, um novo governo deve poder contar com a lealdade partidária dos funcionários, e então substituir os que estão instalados por próximos. No Brasil, ecoa por meio dessa prática a expressão "para os amigos tudo, para os inimigos, a lei”. Em uma capital de estado como Porto Alegre, são cerca de 700 cargos de confiança que estão em jogo a cada eleição municipal. Em 2007, o número era de 2700 para o estado do Rio Grande do Sul (estado brasileiro que conta com menos cargos de confiança) e de até 20000 no nível federal (Tabela 3). Os pleitos eleitorais no Brasil são vetores de uma importante mobilidade política. Milhares de empregos são ameaçados a cada eleição. Se o conhecimento desse desafio incita o pessoal político a não se ligar demais com sua ocupação política e a antecipar a sua saída, certas conjunturas complicam as situações pós-eleitorais. A Tabela 3 apresenta as diferentes esferas constituindo o espaço político profissional no Brasil.

TABELA 3 - O PODER POLITICO: CARGOS ELETIVOS E CARGOS DE CONFIANÇA NO BRASIL

\begin{tabular}{|c|c|c|}
\hline & PODER EXECUTIVO & PODER LEGISLATIVO \\
\hline Federal & $\begin{array}{l}\text { Presidência da República (eleição cada } 4 \\
\text { anos) } \\
22882 \text { cargos de confiança em } 2007 \\
\text { (quase } 4 \% \text { do total dos cargos), repartidos } \\
\text { entre os gabinetes da Presidência da } \\
\text { República e os diversos ministérios e } \\
\text { secretariados de Estado, bem como nas } \\
\text { empresas públicas nacionais. Não } \\
\text { contabilizando estes, o número baixa para } \\
19927 \text {. }\end{array}$ & $\begin{array}{l}\text { Congresso } \\
513 \text { Deputados, eleitos para quatro anos } \\
\text { nos } 27 \text { estados da Federação. O número } \\
\text { de Deputados Federais eleitos é propor- } \\
\text { cional à população dos estados (um } \\
\text { maximo de } 70 \text { deputados para o estado de } \\
\text { São Paulo, } 53 \text { em Minas Gerais, } 46 \text { no Rio } \\
\text { de Janeiro e um mínimo de oito para os } \\
\text { estados menos povoados). Trinta e um } \\
\text { deputados federais são eleitos no Rio } \\
\text { Grande do Sul. } \\
81 \text { Senadores (três em cada um dos } 27 \\
\text { estados da Federação) eleitos por oito } \\
\text { anos e renovados por terço todos os anos } \\
\text { (um terço e seguidamente dois terços). } \\
\text { Todos os congressistas têm vários } \\
\text { colaboradores de confiança. }\end{array}$ \\
\hline Estadual & $\begin{array}{l}\text { Governador (eleição cada quatro anos) } \\
27 \text { Governadores ( } 26 \text { Estados mais um } \\
\text { Distrito Federal). Número de cargos de } \\
\text { confiança variável em função dos estados. } \\
\text { Máximo de } 22800 \text { (Tocantins); } 20800 \text { no } \\
\text { estado de São Paulo; cerca de } 8900 \text { em } \\
\text { Pernambuco e } 2700 \text { para o Rio Grande do } \\
\text { Sul (estado que tem menos). }\end{array}$ & $\begin{array}{l}\text { Assembléia Legislativa (eleição cada } \\
\text { quatro anos) } \\
1059 \text { deputados estatais repartidos por } \\
\text { ponderação nos } 27 \text { estados da Federação, } \\
\text { de } 94 \text { Deputados no estado de São Paulo } \\
\text { a } 30 \text { deputados nos estados menos } \\
\text { povoados. Há } 55 \text { deputados no Rio Grande } \\
\text { do Sul, cada um tem vários colaboradores } \\
\text { (até 18). }\end{array}$ \\
\hline Municipal & $\begin{array}{l}\text { Prefeito (eleição cada quatro anos) } \\
\text { Número de cargos de confiança variável } \\
\text { em função cidade ao outro, e mais } \\
\text { importante nas capitais estatais. No total, } \\
350230 \text { cargos de confiança repartidos } \\
\text { nos } 5564 \text { municípios brasileiros (havia em } \\
2004 \text { mais de } 700 \text { cargos de confiança em } \\
\text { Porto Alegre e } 18302 \text { no conjunto dos } \\
\text { municípios do Rio Grande do Sul). }\end{array}$ & $\begin{array}{l}\text { Câmara dos Vereadores (eleição cada } \\
\text { quatro anos) } \\
\text { O número de vereadores é proporcional à } \\
\text { população da cidade, de sete a } 21 \text { nas } \\
\text { cidades com menos de dois milhões de } \\
\text { habitantes; de } 23 \text { a } 51 \text { para as cidades de } \\
\text { dois a cinco milhões de habitantes e } 53 \text { para } \\
\text { as cidades de mais de cinco milhões de } \\
\text { habitantes. A cidade de Porto Alegre conta } \\
\text { com } 36 \text { vereadores, cada um tendo vários } \\
\text { colaboradores de confiança político (até 12). }\end{array}$ \\
\hline
\end{tabular}

FONTES: O autor, a partir de Agostine, Bueno e Jungerfeld (2006) e Instituto Brasileiro de Geografia e Estatística (IBGE). 
No caso da derrota de PT no Estado do Rio Grande do Sul em 2002, os efeitos colaterais da derrota foram amortecidos com uma dupla absorção do pessoal político, uma absorção por baixo, por meio de um retorno à administração municipal de Porto Alegre (ainda então nas mãos do PT); uma absorção por cima por meio da obtenção de um cargo de confiança em nível federal (o candidato do PT - Lula - tinha vencido a eleição presidencial de 2002). As pessoas que não encontraram um cargo no poder Executivo podiam tentar reinvestir seus capitais e recursos para obter um cargo em uma das instâncias do poder Legislativo (cf. Tabela 3), ou até em uma empresa pública estatal ou nacional. No caso da eleição municipal de 2004 em Porto Alegre, os efeitos colaterais da derrota tiveram consequências maiores para os cargos de confiança. Em primeiro lugar, em um nível quantitativo, porque o leque das possibilidades de reclassificação tinha fechado-se. A maior parte dos cargos disponíveis tinha sido concedida em 2002. As oportunidades de absorção limitavamse aos poucos cargos do poder Legislativo municipal e aos cargos abertos pela vitória de PT em outros municípios. Isso aumentava a concorrência interna para quem queria manterse no espaço político profissional. Em segundo lugar, em um nível qualitativo, devido à duração da experiência petista em Porto Alegre. Certos indivíduos tinham trabalhado oito, 12 , ou até 16 anos em cargos de confiança na administração municipal. Tinham construído sua carreira por meio da política, esquecendo a instabilidade de sua situação e abandonando gradualmente sua profissão inicial (para os que tinham uma atividade profissional prévia).

As derrotas constituem no Brasil um risco importante de exclusão do jogo político. Mas em certos casos a frustração também pode combinar-se a outras variáveis e conduzir a uma saída voluntária da competicão política ou mesmo da esfera política profissional. Além disso, a perturbação limita-se inicialmente à esfera políticoprofissional, mas pode em seguida espalhar-se, por efeito de contágio, a outras esferas da vida (principalmente a esfera familiar, muito próxima da esfera político-profissional no caso do pessoal do PT). Veremos, na última parte, como, uma vez a perturbação estabelecida, opera-se a passagem do momento crucial para o ponto crítico da bifurcação.

\section{DERROTAS ELEITORAIS E BIFURCAÇÕES POLÍTICAS: ALGUNS EXEMPLOS}

"Born to lose

I' ve lived my life in vain

Every dream has only brought me pain" Ted Daffan, Born to lose, 1942.

As derrotas eleitorais podem gerar diferentes tipos de conseqüências para o pessoal político. Entre essas, cabe vislumbrar três: (i) para os candidatos que não ocupavam posições de poder no espaço político (outsiders), as derrotas são barreiras de entrada na política. Vêm quebrar uma ambição e barrar a inserção na carreira política. Mas nesses casos os efeitos das derrotas geralmente não se fazem sentir diretamente ao nível das trajetórias profissionais (que se constroem independentemente do resultado das eleições). As experiências eleitorais constituem, nesses casos, parênteses, e os candidatos derrotados podem retomar suas posições profissionais pré-eleitorais. Eles podem, em certos casos, investir o capital político adquirido durante as experiências eleitorais para integrar o espaço político profissional por outra via (fazendo-se seleccionar como colaboradores); (ii) para os candidatos que já ocupavam um cargo eletivo (incumbents), as derrotas vêm quebrar uma trajetória política em fase de consolidação. Nesses casos, as derrotas não apenas desilusionam uma ambição, mas têm efeitos concretos para os percursos profissionais dos indivíduos. As conseqüências podem ser: (a) a mobilidade política intracampo e a manutenção no espaço político profissional por meio da obtenção de um cargo não eletivo; (b) a saída do espaço político profissional e a reclassificação às margens do campo político; (iii) para as pessoas que não foram candidatas, mas cuja perenidade do emprego no espaço político profissional dependia do resultado eleitoral (assessores, colaboradores, pessoal de confiança político etc.), as derrotas eleitorais vão igualmente afetar os percursos políticos profissionais. Duas consequências também são possíveis. Cada consequência comporta desafios próprios: a) a manutenção no espaço político profissional por meio da integração em uma outra instância de poder; (b) o regresso para a iniciativa privada.

Interessamo-nos aqui pelos dois últimos casos, ou seja, pelas derrotas geradoras de redefinições profissionais. Vários tipos de redefinições são 
possíveis. Consideraremos as experiências de mobilidade no espaço do poder político como bifurcações menores. Por outro lado, as saídas do espaço político profissional serão nomeadas bifurcações radicais (rupturas profissionais).

\section{IV.1. As bifurcações menores, a mobilidade} intracampo político

Os indivíduos que desejam manter-se no espaço político profissional após uma derrota geralmente conseguem adaptar-se às redefinições do campo dos possiveis geradas pelas evoluções da conjuntura política. Eles reduzem assim a amplitude das bifurcações. Para isso, entram em um jogo de dependências e instauram diversas estratégias de mobilização de recursos (individuais e partidários). Como vimos acima, a mobilidade no seio do poder político pode tomar diversas formas, passagem do poder Executivo para o Legislativo (ou contrariamente), mudança de nível de poder (local, estatal e federal) etc. Para analisar as mobilidades políticas dos perdedores (diretos ou indiretos), cabe, conseqüentemente, considerar as flutuações no conjunto das fileiras potenciais de reclassificação. A reclassificação faz-se em geral por baixo. Os indivíduos têm que resolverse a aceitar cargos menos reconhecidos e menos interessantes do que aqueles que ocupavam antes de terem sofrido os efeitos da derrota. A derrota tem, nesse sentido, um impacto negativo na construção da carreira política profissional. No entanto, em certos casos, indivíduos fortemente dotados em capital político podem beneficiar-se de um "prêmio pela derrota". Foi o caso, por exemplo, do ex-Prefeito de Porto Alegre, Tarso Genro. Candidato derrotado para o cargo de Governador do Rio Grande do Sul em outubro de 2002, foi chamado, em janeiro de 2003, pelo Presidente Lula para tornar-se Ministro do Desenvolvimento Econômico e Social, e em seguida Ministro da Educação. Após ter ocupado o cargo de Ministro das Relações Institucionais e a direção temporária do PT nacional, ocupava em 2009 o Ministério da Justiça e era uma das pessoas-chave do governo Lula. O fracasso pessoal que viveu em 2002 não freiou Tarso Genro em sua trajetória política: ele foi de novo candidato a Governador do Rio Grande do Sul em 2010.

A reclassificação política pode, contudo, implicar escolhas pessoais difíceis e até produzir perturbações em outras esferas de vida, mudança, separação etc. No caso de Tarso Genro, ou do antigo Governador do Rio Grande do Sul Olívio Dutra (nomeado Ministro das Cidades por Lula em janeiro de 2003), essa mudança é compensada pelo alto estatuto da nova posição política e pelo nível de responsabilidade conferido: "Onde a gente tem compromisso e responsabilidade, a gente tem que estar ali. Não me senti mal por ter que estar em Brasília. Mas eu já tinha experiência de estar em Brasília com o Lula quando fomos constituintes (1986/1988). Moramos lá em um apartamento. Não levamos as nossas mulheres. Dessa vez, como Ministro, a minha mulher foi também, claro. Brasília tem suas pecularidades. É a cidade da burocracia, inclusive dos privilégios, cidade de automóveis. Evidentemente que, para morar, é um troço. Eu estou em Porto Alegre há 37 anos. Mas também deixei a minha cidade de Luis Gonzaga... Não é questão de gostar ou não gostar. [...] Todas vezes que fui para Brasília foi por compromisso político, por um projeto" (EXPREFEITO DE PORTO ALEGRE, 2007; sem grifos no original).

Essa enfatização do dever político - até do sacrifício pessoal - está presente no discurso de vários entrevistado que ocupam ou ocuparam cargos de alto nível. Em muitos casos, os entrevistados que têm esse discurso consideram que não são profissionais da política. Para outras pessoas, a escolha de um deslocamento para Brasília (centro do poder político federal, Brasília está situada a mais de $2000 \mathrm{~km}$ de Porto Alegre) revelou-se mais difícil. Por motivos pessoais e, às vezes, surpreendentes, alguns recusaram uma reclassificação por cima em Brasília. É o caso, por exemplo, do antigo Secretário da Cultura de Porto Alegre e do Rio Grande do Sul, o falecido Pilla Vares. Em 2003, Pilla Vares recusou uma proposta para ocupar um cargo de assessor de um Ministro em Brasília. Ele preferiu ficar em Porto Alegre, onde encontrou um cargo de Assessor Legislativo na Assembléia Legislativa do Rio Grande do Sul: "Eu fui trotskista toda a minha vida. [...] Eu detesto Brasília. Eu acho que é uma cidade horrivel. Brasília é uma cidade stalinista. Vai lá para conhecer. [O ministro] ficou muito bravo comigo porque ele queria que eu fosse para a assessoria dele. Mas eu disse "não, não vou para Brasília". Eu prefiro mil vezes ficar em Porto Alegre. Brasília é uma cidade horrivel para a gente morar. Sempre pensei, não vou lá. É uma escolha pessoal ficar aqui em Porto Alegre" (EX- 


\section{SECRETÁRIO ESTADUAL DA CULTURADO} RIO GRANDE DO SUL, 2005; sem grifos no original).

De modo contrário, outro assessor enfrentou o desafio de Brasília. Aos 37 anos, ele tinha trabalhado vários anos na administração municipal de Porto Alegre. Sua trajetória política estava em forte ascensão em 2004 quando o PT perdeu a prefeitura. Logo depois da derrota de 2004, recebeu um convite para trabalhar na organização do Fórum Social Mundial (FSM) até ao final de janeiro de 2005. Mas, ao mesmo tempo, Tarso Genro contatou-o para que se tornasse seu assessor de imprensa pessoal no Ministério da Educação (ele tinha participado do comitê de campanha de Tarso Genro em 2002). "Eu tinha que escolher", explica ele. Por um lado, ele podia aceitar uma reclassificação política temporária e por baixo no FSM. Aquilo lhe permitiria permanecer perto da sua família e dar-lhe tempo para procurar uma futura reclassificação. Por outro lado, podia aceitar uma reclassificação política por cima, mas com duração indeterminada e condições de trabalho incertas. Aquilo lhe permitiria dar nova dimensão à sua carreira profissional, aproximando-o das mais altas esferas do poder. Mas também perturbaria a organização de sua vida privada. Ele decidiu tomar a oportunidade que the era oferecida de ver sua carreira evoluir rapidamente, pondo em risco a estabilidade de sua vida privada. Escolhendo o trabalho com um Ministro em Brasília, deixava em Porto Alegre a mulher e duas crianças - para regressar apenas uma vez cada a duas ou três semanas. Um ano depois, ele voltara a Porto Alegre para trabalhar com uma deputada federal e depois como assessor de imprensa da bancada do PT na Câmara dos Deputados de Porto Alegre. Em 2007, finalmente estabeleceu-se por conta própria para trabalhar em casa como freelance na área de comunicação.

As exclusões do espaço político profissional impostas pelas derrotas eleitorais são geralmente temporárias. A reclassificação implica freqüentemente um período de espera e de reformulação por baixo das ambições. Esse período de incerteza e desemprego pode demorar vários meses (de dois a seis meses no que diz respeito às pessoas entrevistadas). Mas a maior parte das pessoas encontradas que mobilizaram recursos para obter uma reclassificação política conseguiram continuar trabalhando no campo político. Se a derrota eleitoral tem efeitos para a construção das carreiras políticas, é mais como freio na evolução da carreira de do que como fator de rupturas profissionais.

\section{IV.2. As bifurcações radicais, as rupturas profis- sionais}

As derrotas podem, no entanto, provocar bifurcações radicais e path shiftings profissionais voluntários. Isso no sentido de que certos fracassos têm efeitos de catalisadores de frustrações. A frustração gera uma série de reflexões sobre a essência mesma da atividade política. Abre a tentação de um afastamento individualista mais ou menos brutal. Para que continuar tendo um papel político ativo? Não é tempo de dedicar-se mais a atividades privadas, familiares ou profissionais não-políticas? Como eventos perturbadores, as derrotas eleitorais podem então conduzir a uma nova hierarquização da escala das prioridades individuais, fazendo que o interesse na ação pública passe para uma posição mais atrás. Esse fenômeno foi teorizado por Albert O. Hirschman (2002) em sua obra Shifting Involvement, Private Interest and Public Action. $\mathrm{O}$ autor considera a evolução das preferências individuais em termos de ciclos ligados a lógicas de insatisfação e de decepção/frustração. Distingue duas variedades de vida ativa, de um lado, a vita activa tradicional, inteiramente dedicada aos negócios públicos; do outro, a busca de uma vida melhor para si mesmo e para os seus próximos, pensada sobretudo como um bem-estar material maior. Sem imaginar uma eventual conciliação desses dois tipos de ação, o autor defende que a passagem de um a outro responde a decepções vividas pelos atores em cada esfera: "Os atos tanto de consumo como de participação nos negócios públicos, que são realizados na esperança de se ter uma satisfação, também trazem decepção e insatisfação. [...] A decepção e a insatisfação são o destino eterno do homem" (idem, p. 26).

No entanto, a decepção tem de atingir um limiar mínimo para causar o afastamento de um espaço para outro. Além disso, a decepção e a frustração não são suficientes para explicar as razões do afastamento. Na explicação das decisões pelas quais os indivíduos bifurcam, também cabe vislumbrar o papel de "uma dúvida e uma indisposição preexistentes [...] com um acontecimento ou uma experiência que age como catalisador" (idem, p.124). É nesse sentido que 
as derrotas eleitorais são elementos de bifurcações. Sem nunca referir-se explicitamente a Hirschman, Bert Klandermans parece ter inspirado-se nele na elaboração de sua teoria sobre a dinâmica sociopsicológica do afastamento. O princípio de base das suas investigações é resumido no esquema seguinte.

FIGURA 1 -ADINÂMICADO AFASTAMENTO

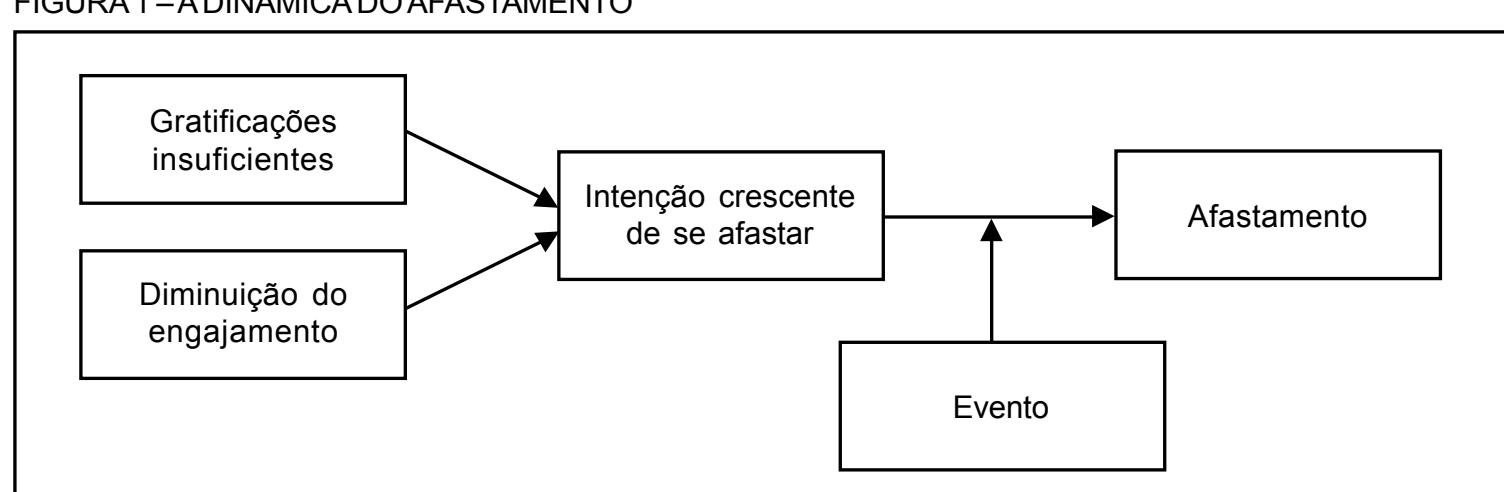

FONTE: o autor, a partir de Klandermans (2005).

Em trabalho intitulado "uma psicologia social do exit", o autor holandês explica a lógica desse esquema nos termos seguintes: "A insuficiência de gratificações, combinada com o declínio do interesse, traduz-se em uma intenção crescente de deixar a função. É quando um evento crítico faz inclinar a balança e provoca a saída. Incontestavelmente, o evento mesmo apenas tem um papel causal. Não se tem que sobrestimar seu impacto. No fim das contas, o afastamento é sobretudo o produto da insuficiência de gratificações e da perda de interesse para a causa" (KLANDERMANS, 2005, p. 95-96).

Se a maior parte das pessoas entrevistadas em nossa pesquisa e que abandonaram o espaço do poder político fizeram-no de maneira voluntária, não é apenas porque foram desiludidas pessoalmente pelo resultado do jogo político e frustradas pela falta de reconhecimento do trabalho realizado. É também por outras razões de ordem privada, os constrangimentos familiares ou afetivos, os constrangimentos financeiros ou geográficos ou ainda o cansaço físico ou psicológico: "O Ministro queria que eu fosse para Brasília com ele, logo que ele assumiu o Ministério, o primeiro em 2003, o Conselho de Desenvolvimento Econômico e Social. Eu preferi não ir. Saí porque eu percebi, na campanha, essa última do Tarso, que eu estava perdendo qualidade no meu trabalho. Não só qualidade de vida, que eu estava gorda, estava mal cuidada, mas qualidade emocional mesmo. Logo depois eu fiquei doente, tive um câncer. [...] E ele viu que realmente o câncer já foi uma decorrência da falta de cuidado com a minha saúde" (EXSECRETÁRIA MUNICIPAL DE PORTO ALEGRE, 2005).

O afastamento dessa mulher que trabalhava em cargo de confiança na administração municipal de Porto Alegre (na área da comunicação) não foi de resto definitivo. Menos de dois anos após essa recusa, ela finalmente aceitou ir trabalhar em Brasília no Ministério da Justiça com o Ministro, onde ela ainda estava no início de 2010. Necessidade alimentar ou saudade do trabalho político? A resposta já estava na frase a seguir, recolhida durante uma entrevista com ela em 2005: "O trabalho político é muito absorvente. E apaixonante. Uma droga. Exatamente. [...] A política aqui me apaixonou".

O estudo realizado com o pessoal político do Rio Grande do Sul confirma em parte as hipóteses de Hirschman e de Klandermans. A derrota age como uma causa que transforma uma tomada de consciência prévia em uma decisão. Assim, as derrotas podem ser pensadas como aceleradores biográficos. É o balanço que faz um ex-Deputado, que definitivamente abandonou o jogo político logo depois de um fracasso eleitoral. Após 20 anos de carreira política (tinha sido eleito Vereador em 1982, em seguida exerceu os cargos de Deputado Estadual e Federal), o fracasso teve esse papel de 
elemento desencadeador: "O caminho mais fácil para mim talvez fosse o caminho de virar um assessor e seguir dependendo da política. Isso eu disse 'não'. Não há chance, eu vou reconstruir a minha vida. E aí, com o passar do tempo, eu resolvi com a minha mulher escrever uma carta agradecendo às pessoas que não votaram em mim. $\mathrm{O}$ fato é que eu nunca escrevi a tal carta. Foi apenas uma ideia que eu não concretizei - até porque eu imaginei que os leitores teriam dificuldade de compreender minha posição e poderiam pensar que eu não estava sendo sincero. Mas que deu vontade de escrever, ah, deu mesmo!" (EX-DEPUTADO FEDERAL DO PTRS TRÊS, 2007; sem grifos no original).

Alguns dias após sua derrota, ele reexaminou uma proposta recebida quando ainda era Deputado Federal para desenvolver um projeto universitário na Inglaterra. Ele elaborou um projeto vinculado com o seu domínio de especialização, Direitos Humanos, (presidira a comissão da área quando Deputado). O projeto foi aprovado e financiado pela Fundação Ford, o que permitiu-lhe ir para Inglaterra com a família. A existência de uma proposta de saída facilitou a sua bifurcação e permitiu-lhe ter um olhar mais crítico em relação à política após a derrota do que tinha quando era Deputado. Mas também a proposta relançada em um momento crucial que lhe permitiu finalmente decidir abandonar a competição política: "Logo depois da derrota, a minha amiga que trabalhava na Universidade Oxford me convidou de novo. Ela me disse 'agora tu não tens mais desculpa, pode vir, vem para cá" (idem).

Uma vez fora da esfera política, ele tomou realmente consciência da situação de dependência em que estivera frente à política. Alguns anos depois do fracasso liberador, ele enfatiza a dificulade do trabalho político, sem mencionar nenhum lado positivo: "Mas lá na Inglaterra eu percebi o quanto que eu havia perdido por ser Deputado, depois de tanto tempo. Porque é uma vida completamente absurda que eu levava, quer dizer, militando todo o tempo, 24 horas por dia, sem ter tempo para a tua família, viajando os finais de semana, fazer reuniões, vivendo angustiado com agenda, com não sei quê, uma vida que $f o i$ também estafante. [...] A pessoa quando está dentro, está metida naquela dinâmica. Não tem condições de pensar. Até não tem como imaginar o que seria. Eu também não imaginava o que seria a minha vida fora da política. Hoje eu não posso imaginar como aguentei tanto tempo" (idem; sem grifos no original).

Atualmente, o ex-Deputado presta consultoria privada na área dos Direitos Humanos e foi aceito no mestrado em Sociologia na Universidade Federal do Rio Grande do Sul. Com sua nova profissão, ele ainda gravita pelas fronteiras do campo político. Ele não tem mais relações institucionais com o PT, mas às vezes encontrase com os seus antigos colegas, que ainda estão com cargos políticos eletivos: "Sabe que eu às vezes vou a Brasília para o trabalho. Quando pego avião eu encontro ex-colegas Deputados indo ou voltando. Eu fico observando eles. As conversas, enfim. E estou pensando 'cara, eu fui assim, desse jeito'. [...] Não, agora me sento no avião, abro um livro, leio, o luxo. Extremamente tranqüilo. É outra qualidade de vida. Inclusive por questão financeira. Uma coisa maluca isso" (idem).

Antes da derrota de 2002, ele nunca tinha construído uma carreira profissional fora da política. Sua carreira eletiva começara em 1982 quando tinha 21 anos. Assim, sua bifurcação torna-se mais radical ainda. É por meio da sua experiência como Deputado que desenvolveu conhecimentos e competências na área dos Direitos Humanos, competências que ele valorizou em seguida para inserir-se no campo universitário (projeto de pesquisa em Oxford, validação de mestrado em Sociologia e inscrição em doutorado). Também pôde valorizar a credibilidade adquirida durante seus mandatos no âmbito dos Direitos Humanos - e ativar a rede relacional tecida ao longo de sua experiência política - para montar sua própria iniciativa de consultoria ("Direitos Humanos e segurança pública"). Trata-se de um caso típico de bifurcação com inversão de competências desenvolvidas ao longo da carreira política. Mas o retorno do pessoal político para profissões não políticas geralmente não se faz de maneira tão fluída como no caso aqui apresentado.

\section{IV.3. Os constrangimentos de uma bifurcação radical}

Que seja voluntário ou sofrido, o retorno para a iniciativa privada defronta-se com vários tipos de constrangimentos. As principais dificuldades sofridas pelo pessoal político do PT no Rio Grande do Sul estão ligadas à desaprendizagem profissional, às evoluções do mercado do trabalho, assim como à influência da cor política. 
O processo de profissionalização política "implica, no curso de uma vida, uma lenta ou brusca separação (tudo depende dos recursos em um sentido sociológico, e da trajetória anterior) da primeira atividade profissional; se é que há uma atividade profissional anterior" (OFFERLÉ, 1999, p. 15). Quanto maior o tempo passado por um indivíduo na carreira política, maior a tendência a afastar-se da sua profissão de origem. Um veterinário ou um cirurgião perde a mão por falta de prática; um operário metalúrgico perde as formações que permitem adaptar-se às evoluções tecnológicas na sua área etc. Para várias profissões, uma longa experiência governamental pode causar uma deshabilitação para o trabalho inicial. Esse movimento de separação foi qualificado de "teoria das tesouras" pelo Sociólogo alemão Dietrich Herzog. Além disso, as redes profissionais distendem-se durante o período de participação política; e as exigências salariais aumentam. Em um mercado de trabalho cada vez mais competitivo, isso complica ainda a reinserção profissional: "Quando sai, tu perdeu um tempo. Isso é uma avaliação que eu faço hoje. Agora. Nós, de esquerda, petistas, doamos muito para o projeto. Entregamos e deixamos lá todo um trabalho, toda uma carreira, exatamente para os projetos de gestão pública. E quando você volta ao mercado, estáfora do mercado, tu é um intruso, desaprendeu, perdeu espaço, perdeu tempo. Isso é uma ingenuidade. Tu é eliminado" (EX-CARGO DE CONFIANÇA DA SECRE-TARIA MUNICIPAL DA CULTURA DE PORTO ALEGRE E MÚSICO, 2005; sem grifos no original).

Para certas profissões, uma estigmatização política acrescenta-se a estas deficiências. Os indivíduos ver-se-ão a recusar a entrada ou o retorno em certos círculos profissionais devido à sua atividade política prévia. No Rio Grande do $\mathrm{Sul}$, - devido às relações difíceis entre os principais órgãos de imprensa (em particular a RBS) e PT os jornalistas que entrevistamos queixaram-se dessa "caça às bruxas", especialmente nos grandes veículos da imprensa escrita, Zero Hora e Correio do Povo: "É, é bem difícil mesmo, tem vários colegas que estão mal. Quem trabalhou no governo petisa tem um carimbo. A gente tem uma estrela na testa. No meu caso por exemplo, se eu fosse pedir emprego na Zero Hora, ou no Correio do Povo, eles não iam me dar emprego, porque eu tenho uma estrela no peito, um carimbo de petista. Uma marca" (EX-CARGO DE
CONFIANÇADA SECRETARIAMUNICIPALDA COMUNICAÇÃO SOCIAL DE PORTO ALEGRE, JORNALISTA E ASSESSOR PARLAMENTAR, 2005; sem grifos no original).

"Trabalhei 12 anos na Zero Hora. Estou trabalhando em jornalismo desde mais de 30 anos. [...] Apesar de ser simpatizante do PT, eu não sou filiado. Não sou um militante. Nunca entrei na militância. [...] Mas sempre tem uma marca porque trabalhei na prefeitura, eu era cargo de confiança. Claro que isso fecha algumas portas, isso reduz ainda mais o mercado que já é complicado" (EX-CARGO DE CONFIANÇA DA SECRETARIA MUNICIPAL DA COMUNICAÇÃO SOCIAL DE PORTO ALEGRE E JORNALISTA FREELANCE, 2005; sem grifos no original).

No entanto, seria precoce tirar conclusões gerais a respeito da relação entre profissão de origem, profissão política e profissão de reconversão. Como notava Pierre Bourdieu com relação às reclassificações do domínio privado para outra esfera do domínio privado, existe "um trabalho de reconversão, mais ou menos bem sucedido, que realizam os agentes particulares, segundo lógicas que dependem em cada caso das suas situações singulares" (BOURDIEU, 1978, p. 7). Do mesmo modo, as condições de reinserção dependerão em cada caso da conjuntura local do mercado de trabalho para uma profissão dada, assim como das particularidades políticas e culturais historicamente constituídas e que influenciam as relações público-privado em um dado lugar.

A justaposição desses fatores (desaprendizagem, contração do mercado de trabalho e estigmatização) complica a reinserção fora do campo político e explica em parte por que a maior parte das bifurcações são de tipo bifurcações menores. O custo de uma bifurcação radical é geralmente elevado. A decepção e a frustração podem gerar um desejo de afastamento, mas a realização da saída dependerá sobretudo das possibilidades de reinvestimento de recursos de cada indivíduo (capital econômico, capital social, capital cultural etc.) e do tipo de profissão desejado.

\section{CONCLUSÕES}

Mostramos que uma abordagem pelo modelo sociológico da caminhada pode permitir melhorar o entendimento da relação entre derrotas eleitorais 
e carreiras políticas, relação que vem sendo trabalhada quantitativamente desde os anos 1980 pela Ciência Política norte-americana. Nesse sentido, acreditamos que as metodologias qualitativas e quantitativas são complementares. Consideramos que a interação entre os diferentes procedimentos metodológicos poderiam alimentar o potencial explicativo das pesquisas sobre a derrota eleitoral. Neste artigo, interessamo-nos pela derrota como fator de discontinuidade nos processos de construção das carreiras políticas. No espírito dos trabalhos sobre a imprevisibilidade nos percursos sociais e sobre as bifurcações biográficas, consideramos as derrotas eleitorais como elementos perturbadores suscetíveis de influenciar o percurso do pessoal político. A partir de uma consideração do tempo como heterogêno e descontínuo, observamos o que provoca as bifurcações do pessoal político profissional ou em fase de profissionalização. Chegamos à conclusão de que certos tipos de derrotas (particularmente os fracassos eleitorais) podem constituir elementos de perturbação e provocar bifurcações. Nesse sentido, o tempo breve das derrotas influencia o tempo médio das carreiras políticas.

Essa influência exerce-se em vários níveis: $(i)$ objetivamente, sobre os atores, de maneira direta (candidato não eleito ou não reeleito) ou indireta (colaboradores demitidos das suas funções por causa da não eleição de um candidato). Os indivíduos que perdem seu emprego por causa de uma derrota sofrem uma mobilidade forçada. Eles têm de reclassificar-se. De acordo com a lógica do cruzamento, essa reclassificação pode fazer-se seja no espaço político profissional, seja fora desse espaço; (ii) subjetivamente, sobre os sentimentos e as emoções dos indivíduos. A influência da derrota faz-se sentir em um prazo curto, até instantâneo. O momento de conscientização de um fracasso eleitoral provoca um período de fluidez e de confusão para o pessoal político. Os fracassos são catalisadores de frustrações. Perante o fracasso, os indivíduos sentem decepção e frustração. Isso pode influenciar a decisão e também a evolução do percurso profissional. Nesse sentido, as derrotas podem ser elementos desencadeadores que produzem um desejo de ruptura profissional e de afastamento do espaço político profissional.

Distinguimos em nossa análise dois tipos de bifurcações posteriores às derrotas eleitorais. Falamos de bifurcações menores quando se trata de uma mobilidade profissional no seio do espaço político profissional. Falamos de bifurcações radicais quando se trata de uma saída (voluntária ou sofrida) do espaço político profissional.

As bifurcações menores são as mais prováveis. Põem em relação vários níveis de poder (local, regional e nacional). Os indivíduos que desejam manter-se no espaço político profissional após uma derrota devem adaptar-se às redefinições do campo dos possíveis causadas pelas evoluções da conjuntura política. Elas entram em um jogo de dependências e organizam diversas estratégias de mobilização de recursos (individuais e partidários). A reclassificação intracampo faz-se em geral por baixo: os indivíduos têm de aceitar cargos menos reconhecidos e menos interessantes do que aqueles que ocupavam antes de terem sofrido os efeitos da derrota. Mas a reclassificação também pode fazer-se pelo nível superior. Fala-se nesse caso de um "prêmio pela derrota".

Apesar dos efeitos dos fracassos eleitorais em termos de decepções e de frustrações, as bifurcações radicais são mais raras. Por várias razões (desaprendizagem profissional, estreitamento do mercado do trabalho e estigmatização política), o custo de uma saída do espaço político profissional pode ser alto. A probabilidade de uma inversão de recursos improdutiva e de um prolongamento indeterminado do período de desemprego é mais importante fora do campo político do que dentro. Sem oportunidade concreta de emprego fora do espaço político, os indivíduos desiludidos pela derrota e frustrados pela ação política podem, assim, ter um desejo de saída e não formalizá-lo. O racional toma então o passo sobre o emocional. A segurança de uma mobilidade intracampo (menos atrativa mas mais provável) vence o risco de uma saída desejada mas descontrolada.

Para Erving Goffman, a história de um compromisso pessoal pode terminar de três maneiras para um indivíduo: (i) ser beneficiado por uma promoção; (ii) abdicar e trocar de papel voluntariamente; (iii) ser privado da sua posição. É na terceira situação que o indivíduo entra em situação de malogro e é necessário "acalmar o enganado" (GOFFMAN, 1989, p. 281-283). A privação de um papel ou de uma posição pode fazer-se de duas maneiras. Em certos casos (a terceira), a perda do estatuto não se faz sentir 
sobre o perdedor e "a humilhação não se acrescenta à dor" (acidente, doença etc.). O perdedor pode, contudo, precisar ser acalmado para aceitar a sua perda. Os colaboradores de candidatos não eleitos podem entrar nessa categoria, porque eles não têm em geral uma responsabilidade pessoal na derrota. Em outros casos, o malogro vem confirmar uma falta de aptidão para exercer o cargo ou o papel desejado. Esse tipo de perda é humilhante e vergonhoso. É o caso de alguns candidatos derrotados e indivíduos que envolvidos pessoalmente na conquista ou na conservação do papel. Do ponto de vista do perdedor, o apaziguamento representa um processo de ajustamento a uma situação impossível (idem, p. 287). Para o pessoal político profissional, esse ajustamento pode fazer-se de várias das maneiras sugeridas por Goffman: (i) a gestão temporal e a obtenção de uma nova oportunidade de qualificar-se para exercer o papel perdido ou não obtido; (ii) a obtenção de um cargo diferente daquele que foi perdido ou não obtido, mas que permite conservar um estatuto aceitável e permanecer no mesmo ambiente; (iii) a obtenção de um cargo que confere um estatuto considerado equivalente, mas exercido em um ambiente diferente.

Nos dois últimos casos, o apaziguamento passa por uma bifurcação, menor ou radical. Ao contrário de uma punição suplementar, a bifurcação tem então uma função catártica e permite digerir a pílula do malogro.

Frédéric Louault (frederic.louault@opalc.org) é Doutor em Ciência Política pela Sciences Po Paris (França), Professor de Ciência Política na Sciences Po Paris, no Instituto de Altos Estudos da América Latina, da Universidade Sorbonne Nouvelle (Paris) e no Instituto de Estudos Políticos de Grenoble (França).

\section{REFERÊNCIAS BIBLIOGRÁFICAS}

ABBOTT, A. 2001. Time Matters. On Theory and Method. Chicago: University of Chicago.

ABELES, M. 2005. L'échec en politique. Paris: Circé.

AGOSTINE, C.; BUENO, S. \& JUNGERFELD, V. 2006. São Paulo tem mais cargos comissionados do que o governo do Brasil. Valor Econômico, São Paulo, 18.dez.

ALAIN [Emile-Auguste Chartiet]. 1985. Propos sur les pouvoirs. Paris: Gallimard.

AUROUX, S. (ed.). 1998. Dictionnaire des notions philosophiques. V. 1. Paris: PUF.

BACHELARD, G. 1992. L'intuition de l'instant. Paris: Stock.

BIDART, C. 2006. Crises, décisions et temporalités: autour des bifurcations biographiques. Cahiers internationaux de sociologie, Paris, n. 120, p. 29-57.

BON, F. \& BURNIER, M. A. 1985. Que le meilleur perde. Eloge de la défaite en politique. Paris: Balland.

BOURDIEU, P. 1978. Classement, déclassement, reclassement. Actes de la Recherche en
Sciences Sociales, Paris, n. 24, p. 2-22. Disponível em: http://www.persee.fr/ articleAsPDF/arss_0335-5322_1978_num 24_1_2613/article_arss_0335-5322_1978_ num_-_4_1_2613.pdf. Acesso em: 14.set.2011.

CABANEL, P. \& LABORIE, P. (eds.). 2002. Penser la défaite. Toulouse: Privat.

CIORAN, E. 1993. Bréviaire des vaincus. Paris: Gallimard.

CONINCK, F. \& GODARD, F. 1990. L'approche biographique à l'épreuve de l'interprétation. Les formes temporelles de la causalité. Revue Française de Sociologie, Paris, n. 31, p. 23-54. Disponível em: http:// www.persee.fr/articleAsPDF/rfsoc 0035 2969_1990_num_31_1_1078/article_rfsoc 0035-2969_1990_num_31_1_1078.pdf. Acesso em: $\overline{1} 4$.set.2011.

DOBRY, M. 1986. Sociologie des crises politiques. Paris: FNSP.

FARGE, A. 2002. Penser et définir l'événement en histoire. Terrain, n. 38, p. 69-78. Disponível em: http://terrain.revues.org/pdf/1929. Acesso em: 14.set.2011. 
FLORENTINO, R. 2008. Saindo de cena. Parlamentares que desistem da disputa eleitoral (1990-2006). Revista de Sociolgia e Política, Curitiba, v. 16, n. 30, p. 45-63, jun. Disponível em: http://www.scielo.br/pdf/rsocp/v16n30/ 05.pdf. Acesso em: 14.set.2011.

FRANTZICH, S. E. 1978. De-Recruitment: The Other Side of the Congressional Equation. The Western Political Quarterly, Sacramento, v. 31, n. 1, p. 105-126, Mar.

GAÏTI, B. 1990. Des ressources politiques à valeur relative: le difficile retour de Valéry Giscard d'Estaing. Revue Française de Science Politique, Paris, v. 40, n. 6, p. 902-917. Disponível em: http://www.persee.fr/article AsPDF/rfsp_0035-2950_1990_num_ $40 \_6 \_394527 /$ article_rfsp_00352950_1990_num_40_6_394527.pdf. Acesso em: $\overline{1} 4$. set.2011.

GILMOUR, J. B. \& ROTHSTEIN, P. 1996. A Dynamic Model of Loss, Retirement and Tenure in the U.S. House of Representatives. The Journal of Politics, Statesboro, v. 58, n. 1, p.54-68, Feb.

GLASER, B. 1998. Doing Grounded Theory. Issues and Discussions. Mill Valley: Sociology.

GLASER, B. \& STRAUSS, A. 1967. The Discovery of Grounded Theory. Strategies for Qualitative Research. Chicago: Aldine.

GOFFMAN, E. 1989. Calmer le jobard. Quelques aspects de l'adaptation à l'échec. In: Le parler frais d'Erving Goffman. Paris: Minuit.

GROSSETTI, M. 2004. Sociologie de l'imprévisible. Dynamiques de l'activité et des formes sociales. Paris: PUF.

HERRICK, R. \& NIXON, D. L. 1996. Is There Life After Congress? Patterns and Determinants of Post-Congressional Careers. Legislative Studies Quarterly, Iowa, v. 21, n. 4, p. 489-449, Nov.

HIBBING, J. R. 1982. Voluntary Retirement from the U.S. House of Representatives. Who Quits? American Journal of Political Science, Bloomington, v. 26, n. 3, p. 467-484, Aug.

HIRSCHMAN, A. O. 2002. Bonheur privé, action publique. Paris: Fayard.
KIM, L. C., 1970. Political Attitudes of Defeated Candidates in an American State Election. The American Political Science Review, Washington (DC), v. 64, n. 3, p.879-887, Sept.

KIM, L. C. \& RACHETER, D. P. 1973. Candidates' Perception of Voter Competence. A Comparison of Winning and Losing Candidates. The American Political Science Review, Washington (DC), v. 67, n. 3, p. 906913, Sept.

KLANDERMANS, B. 2005. Une psychologie sociale de l'exit. In: FILLIEULE, O. (ed.). Le désengagement militant. Paris: Belin.

LACROIX, J. (ed.). 1968. Les hommes devant l'échec. Paris: PUF.

1969. L'échec. Paris: PUF.

LAFORGUE, R. 1993. Psychopathologie de l'échec. Paris: Trédaniel.

LARGEAUD, J.-M. 2006. Napoléon et Waterloo. La défaite glorieuse de 1815 à nos jours. Paris: La Boutique de l'Histoire.

MILLOUD, C. 2000. L'échec en politique. Contribution à l'étude des représentations et des stratégies de légitimation des candidats français. Grenoble. Tese (Doutorado em Ciência Política). Université Pierre MendèsFrance.

MONCRIEF, G. F. 1998. Terminating the Provincial Career, Retirement and Electoral Defeat in Canadian Provincial Legislatures, 1960-1997. Canadian Journal of Political Science, Cambridge (UK), v. 31, n. 2, p. 359372, June.

MOORE, M. K. \& HIBBING, J. R. 1992. Is Serving in Congress Fun Again? Voluntary Retirements from the House Since the 1970s. American Journal of Political Science, Bloomington, v. 36, n. 3, p. 824-828, Aug.

OFFERLÉ, M. 1996. Entrées en politique. Politix, Paris, v. 9, n. 35, p. 3-5. Disponível em: http:/ /www.persee.fr/articleAsPDF/polix_0295$2319 \_1996 \_n u m \_9 \_35 \_1952 /$ a $\mathrm{r}$ t i c 1 e $-\mathrm{p}$ o $1 \mathrm{i} \mathrm{x}_{-} 0295$ 2319_1996_num_9_35_1952.pdf. Acesso em: 14.set.2011.

(ed.). 1999. Profession politique, $19^{e}-20^{\circ}$ siècles. Paris: Belin. 
RAGARU, N. 2004. En quête de notabilité. Vivre et survivre en politique dans la Bulgarie postcommuniste. Politix, Paris, v. 17, n. 67, p. 71-99. Disponível em: http://www.persee.fr/ articleAsPDF/polix_0295-2319_2004_ num_17_67_1625/article_polix_0295-2319 2004_num_17_67_1625.pdf. Acesso em: 11.set.2011.

RAY, D. 1976. Voluntary Retirement and Electoral Defeat in Eight State Legislatures. The Journal of Politics, Statesboro, v. 38, n. 2, p.426-433, May.

SAMUELS, D. 2003. Ambition, Federalism, and Legislative Politics in Brazil. Cambridge (UK): Cambridge University.

STRAUSS, A. \& CORBIN, J. 2004. Les fondements de la recherche qualitative. Techniques et procédures de développement de la recherche enracinée. Fribourg: Academic Press Fribourg.
SCHEIER, M. F. \& CARVER, C. S. 1990. What Really Predicts Electoral Defeat? Psychological Inquiry, Abingdon, v. 1, n. 1, p. 70-73.

SCHLESINGER, J. 1966. Ambition and Politics: Political Careers in the United States. Chicago: R. McNally.

THUILLIER, G. 1992. Le jeu politique. Paris: Economica.

VAÏSSE, M. (ed.). 1994. La défaite. Etudes offertes à Annie Rey-Goldzeiguer. Reims: Presses Universitaires de Reims.

WEBER, M. 2004. Le savant et le politique. Paris: Plon.

ZULLOW, H. M. \& SELIGMAN, M. E. P. 1990. Pessimistic Rumination Predicts Defeat of Presidential Candidates, 1990 to 1984. Psychological Inquiry, Abigdon, v. 1, n. 1, p. 52-61.

\section{OUTRAS FONTES}

EX-CARGO DE CONFIANÇADA SECRETARIA MUNICIPAL DA CULTURA DE PORTO ALEGRE E JORNALISTA FREELANCE. 2005. Entrevista concedida ao autor. Porto Alegre, 28.abr.

EX-CARGO DE CONFIANÇADA SECRETARIA MUNICIPAL DA CULTURA DE PORTO ALEGRE E MÚSICO. 2005. Entrevista concedida ao autor. Porto Alegre, 28.abr.

EX-CARGO DE CONFIANÇADA SECRETARIA MUNICIPAL DA CULTURA DE PORTO ALEGRE E PROFESSORA EM ESCOLA PÚBLICA. 2005. Entrevista concedida ao autor. Porto Alegre, 30.abr.

EX-CARGO DE CONFIANÇADA SECRETARIA MUNICIPAL DE COMUNICAÇÃO SOCIAL DE PORTO ALEGRE E JORNALISTA FREELANCE. 2005. Entrevista concedida ao autor. Porto Alegre, 27.abr.

EX-CARGO DE CONFIANÇADA SECRETARIA MUNICIPAL DA COMUNICAÇÃO SOCIAL DE PORTO ALEGRE, JORNALISTA E ASSESSOR PARLAMENTAR, 2005. Entrevista concedida ao autor. Porto Alegre, 23.abr.
EX-DEPUTADO FEDERAL DO PT-RS UM E CONSULTOR FREELANCE EM POLÍTICAS PÚBLICAS. 2007. Entrevista concedida ao autor. Porto Alegre, 22.nov.

EX-DEPUTADO FEDERAL DO PT-RS DOIS. 2007. Entrevista concedida ao autor. Porto Alegre, 22.nov.

EX-DEPUTADO FEDERAL DO PT-RS TRÊS 2007. Entrevista concedida ao autor. Porto Alegre, 22.nov.

EX-PREFEITO DE PORTO ALEGRE E EXMINISTRO DA REPÚBLICA, 2007. Entrevista concedida ao autor. Porto Alegre, 9.out.

EX-SECRETÁRIO ESTADUAL DA CULTURA DO RIO GRANDE DO SUL. 2005. Entrevista concedida ao autor. Porto Alegre, 11.maio.

EX-SECRETÁRIO MUNICIPAL DE HABITAČ̃̃O DE PORTO ALEGRE E FUNCIONÁRIO PÚBLICO. 2005. Entrevista concedida ao autor, Porto Alegre, 26.abr.

EX-SECRETÁRIA MUNICIPAL DE PORTO ALEGRE. 2005. Entrevista concecida ao autor. Porto Alegre, 23.abr. 
ELECTORAL DEFEATS AND POLITICAL CAREERS: THE CASE OF THE RIO GRANDE DO SUL WORKERS' PARTY (PT)

Frédéric Louault

The purpose of this article is to demonstrate the importance of defeat in electoral competition, thus inverting the classical focus of electoral analysis. Often forgotton within (or left out of ) work in Political Science, the theme of electoral defeat raises crucial problems for our understanding of the 
democratic political game. Through a study of Workers' Party (PT) electoral experiences in the Brazilian state of Rio Grande do Sul between 1982 and 2008, we present some of the challenges of electoral defeats in relation to the construction of the political careers of collaborating candidates: reactions to defeat and acceptance of the rules of the game; mobilization of resources and mobility within the political field; political breaks and exit from professional politics. In the first part of this work, we propose a sociological model of trajectory (and more precisely, the "bifurcation submodel") as a frame of analysis that enables us to renew classical approaches to the relations between electoral defeat and political career. On this basis, we are able to show how some defeats may be upsetting elements that influence the trajectory of political personnel. This is followed by our conclusions, in which we present some concrete forms of direct or indirect bifurcation generated by electoral defeat: both those of the smaller and the more radical sort.

KEYWORDS: electoral competition; electoral analysis; defeat; Workers' Party; Rio Grande do Sul. 


\section{LES ÉCHECS ÉLECTORAUX ET LES CARRIÈRES POLITIQUES : LE CAS DU PT À RIO GRANDE DO SUL}

\section{Frédéric Louault}

L'objectif de l'article, c'est de montrer l'importance des échecs à la compétition électorale, inversant ainsi l'approche traditionnelle de l'analyse électorale. Souvent négligé dans les travaux de Science Politique, le thème de l'échec électoral soulève des questions cruciales pour comprendre le jeu politique et démocratique. En étudiant les expériences électorales du Parti des Travailleurs (PT) à Rio Grande do Sul entre 1982 et 2008, nous présentons quelques défis des échecs électoraux par rapport à la construction des carrières politiques des candidats collaborateurs: les réactions aux échecs et l'acceptation aux règles du jeu ; la mobilisation de ressources et mobilités dans le domaine politique ; des ruptures politiques et les sorties de l'espace politique professionnel. Dans la première partie de ce travail, nous proposons le modèle sociologique de la marche (et plus précisément le « sous-modèle de bifurcation»), comme un cadre d'analyse qui permet de renouveler l'analyse classique des relations entre les échecs électoraux et les carrières politiques. Appuyés sur cela, nous montrons que quelques échecs peuvent constituer des éléments de perturbation et influencer le parcours du personnel politique. En suite, nous concluons l'article en présentant quelques formes concrètes de bifurcations directe ou indirectement produites par des échecs élctoraux : les bifurcations les plus petites et les bifurcations les plus radicales.

MOTS-CLÉS: la compétition électorale ; l'analyse électorale ; l'échec ; le Parti des Travailleurs ; Rio Grande do Sul. 